\title{
PEMAHAMAN KONSEP MELALUI PENDEKATAN PENDIDIKAN MATEMATIKA REALISTIK INDONESIA PADA MATERI PENGUKURAN SUDUT DI KELAS IV SEKOLAH DASAR
}

\author{
Fina Amalena Mariyana \\ Imam Agung Rosady \\ Nurul Latifah
}

\author{
Universitas Muhammadiyah Prof. DR. Hamka \\ Jl. Warung Buncit No.17 Pancoran, Jakarta Selatan \\ email: finaamalenarosady@gmail.com; imamagungrosady@yahoo.com; ipe3h.aja@gmail.com
}

\begin{abstract}
The purpose of this research is to prove whether the implementation of Indonesian Mathematics Realistic Method Approach can enhance the results of mathematics learning by conceptual understanding of angle measurement material for students in Grade IV, SDN Rawa Buaya 03 Pagi. This research is classified as an experimental research with one group pretestposttest design. This research finds out that 12 students (43\%) become the majority in 'good' category. The average percentage of the emergence of all of the conceptual understanding indicators is $78.57 \%$ thus falls in 'good' category. Based on this research, it is concluded that there are enhancements on students' learning results and conceptual understanding in angle measurement material by way of using its method.
\end{abstract}

Keywords: mathematics, student learning, mathematics realistic, angle measurement

\begin{abstract}
Abstrak: Penelitian ini bertujuan untuk mengetahui apakah penerapan metode Pendekatan Pendidikan Matematika Realistik Indonesia (PMRI) dapat meningkatkan hasil belajar matematika melalui pemahaman konsep materi besar sudut pada siswa kelas IV SDN Rawa Buaya 03 Pagi. Penelitian ini merupakan penelitian eksperimen dengan desain rancangan one group pretest posttest. Diperolehhasil penelitian bahwa siswa yang memiliki kemampuan pemahaman konsep kategori baik memiliki frekuensi terbanyak yaitu 12 siswa (43\%).Persentase rata-rata kemunculan keseluruhan dari indikator pemahaman konsep adalah 78,57\% dengan kategori baik.Berdasarkan hasil penelitian, dapat disimpulkan bahwa terdapat peningkatan hasil belajar siswa dan pemahaman konsep pada materi besar sudut melalui PMRI.
\end{abstract}

Kata Kunci : Matematika; Hasil Belajar Siswa; PMRI; Pengukuran Sudut

Dalam rangka meningkatkan mutu pendidikan dan pengajaran diperlukan adanya suatu upaya dalam memilih metode, teknik, strategi serta media pembelajaran agar dapat diperoleh peningkatan hasil belajar siswa khususnya pada mata pelajaran matematika. Matematika adalah salah satu cabang ilmu pengetahuan yang selalu dapat dipelajari oleh setiap anak siswa di lembaga pendidikan formal baik mulai dari tingkat TK (Taman Kanak-Kanak) sampai dengan tingkat Perguruan Tinggi. Konsep-konsep matematika dapat digunakan untuk membantu siswa mengembangkan potensi intelektual yang ada dalam dirinya serta memudahkan mempelajari bidang-bidang ilmu lain (Darsono, 2010).

Matematika merupakan pelajaran yang sangat penting dalam kehidupan manusia karena matematika berasal dari pengalaman atau kegiatan manusia secara nyata yang diciptakan oleh Allah sendiri (Brummelen, 2008). Hal ini ditekankan kembali melalui Peraturan Menteri Pendidikan Nasional Re- 
publik Indonesia (PerMendiknas RI) Nomor 22 Tahun 2006 bahwa matematika mendasari perkembangan kemajuan teknologi, matematika punya peran penting dalam berbagai disiplin, dan memajukan daya pikir manusia (Husna, dkk, 2013).

Pengukuran sudut merupakan salah satu cabang dalam bidang ilmu matematika yang mempelajari tentang geometri. Pada dasarnya pengukuran sudut dapat dilakukan dengan cara yang mirip dalam mengukur atribut lainnya, seperti panjang. Seperti panjang dan luas yang dasar pengukurannya terletak pada pemahaman konsep-konsep seperti partisi yang sama dan satuan literasi untuk memahami sudut dan ukurannya (Clements dan Stephan, 2004; Clements dan Sarama, 2009 ). Hal ini diungkapkan Clements dan Sarama (2009) bahwa metode pengukuran sudut didasarkan pada pembagian lingkaran. Pengukuran sudut merupakan salah satu materi dari mata pelajaran matematika di kelas IV Sekolah Dasar (SD). Sudut memiliki manfaat dalam kehidupan sehari-hari yaitu berguna untuk menghitung tinggi benda, sebagai bidang miring untuk memudahkan pekerjaan, dan sudut digunakan dalam keindahan dan kekuatan pada bangunan (Damaruta, 2015).

Pengukuran sudut merupakan materi yang sulit bagi siswa. Hal ini sejalan dengan yang dinyatakan oleh Lehrer (2003) bahwa ada dua masalah yang berkaitan dengan pengukuran sudut, pertama adalah siswa mengetahui bahwa panjang sinar membangun sudut yang memiliki efek pada pengukuran sudut, hal ini mungkin disebabkan oleh siswa yang hampir selalu mengukur dari ujung sinar sehingga mereka mengetahui bahwa pengukuran sudut adalah jenis lain dari pengukuran panjang dan jarang memahami bahwa sudut adalah pengukuran rotasi, dan masalah kedua adalah bahwa siswa mengetahui sudut dalam posisi ini memiliki luas pada pengukuran sudut itu.

Pada studi pendahuluan diperoleh hasil bahwa sebanyak 20 siswa (71\%)belum memenuhi Kriteria Ketuntasan Minimal (KKM) kelas IV SDN Rawa Buaya 03 Pagi yaitu 67. Hal ini menunjukan rendahnya tingkat penguasaan siswa terhadap materi mata pelajaran matematika, khususnya pada materi besar sudut.Selain perolehan hasil post test, dalam melakukan pengukuran sudut ternyata sebagian siswa masih kesulitan ketika menggunakan alat ukur seperti penggaris dan busur derajat sehingga sebagian siswa selalu tidak tepat dan tidak teliti dalam mengukur sudut. Mereka juga terlihat cemas kurang percaya diri dalam mengemukakan setiap hasil pengukuran tersebut sehingga suasana pembelajaran menjadi pasif.

Untuk mengatasi permasalahan pada pembelajaran matematika tersebut, maka guru perlu mendesain pembelajaran yang lebih bermakna pada materi besar sudut. Peneliti akan melakukan suatu penelitian design research yang mengembangkan serangkaian aktivitas menggunakan pendekatan Pendidikan Matematika Realistik Indonesia (PMRI) yang lebih menekankan pada kebermaknaan konsep. PMRI atau Realistic Mathematic Education (RME) adalah suatu teori tentang pembelajaran yang salah satu pendekatannya menggunakan konteks dunia nyata dan berdasarkan pengalaman yang telah didapatkan siswa sebagai titik tolak belajar matematika (Oftiana, Siti. dan Saefudin A. A., 2017.) PMRI merupakan suatu gerakan untuk mereformasi pendidikan matematika di Indonesia. Jadi bukan hanya suatu metode pembelajaran matematika, tapi juga suatu usaha melakukan transformasi sosial (Sembiring, 2007). Karakteristik dari pendekatan tersebut adalah siswa lebih aktif berpikir, konteks dan bahan ajar terkait langsung dengan lingkungan sekolah dan siswa, peran guru lebih aktif dalam merancang bahan ajar dan kegiatan kelas.

Saefudin (2012) menyatakan bahwa prinsip PMRI sama dengan RME meskipun dalam beberapa hal PMRI berbeda dengan RME karena konteks, budaya, sistem sosial dan alamnya yang berbedabeda. Pendekatan PMRI telah berlangsung sejak tahun 2001 (Zulkardi, 2009) dan telah banyak digunakan dalam setiap upaya untuk memperbaiki minat siswa, sikap, dan hasil belajar siswa.

Dari ketiga prinsip tersebut Gravemeijer mengembangkan tingkatan model PMR menjadi 4 dalam Zandiech \& Rasmussen (2010, p.58) dan Zulkardi (2002, p.31) yang digambarkan sebagai berikut.

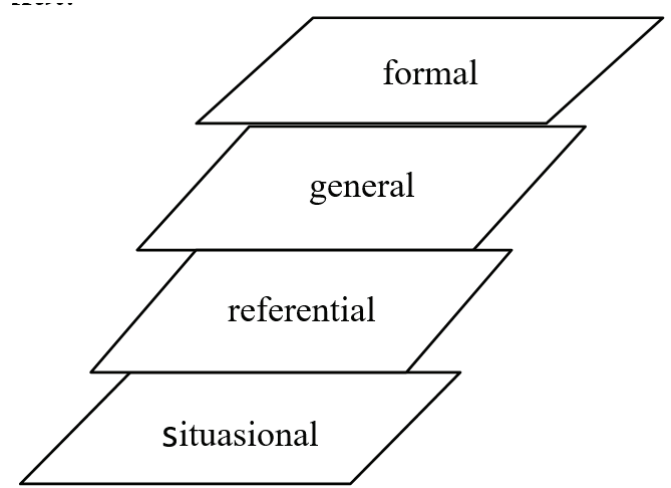

Gambar 1. Tingkatan model PMR 
Keempat tingkatan tersebut adalah situation (situasi), model of (model dari), model for (model untuk), formal mathematics (matematika formal). Titik awal mula pembelajaran PMRI yang haruslah berangkat dari hal yang nyata bagi siswa sehingga dapat mendorong siswa untuk terpaut dengan situasi tersebut. Inilah yang menjadi karakteristik dalam PMRI. Hal yang serupa dituturkan oleh De Lange dalam Fauzan, (2002, p.44) dan Gravemeijer dalam Zulkardi (2002, p.29) bahwa RME memiliki 5 karakteristik dari RME antara lain: (1) the use of real-life contexts/penggunaan masalah kontekstual, (2) the use of use models/penggunaan model sebagai jembatan, (3) student's free production/penggunaan kontribusi dan kreativitas siswa, (4) interaction/ interaktivitas, dan (5) intertwining/keterkaitan.

PMRI sejalan dengan pembelajaran matematika dalam kurikulum 2013 yang menekankan pada proses pencarian pengetahuan. Setiap siswa diarahkan untuk dapat menemukan sendiri berbagai fakta, membangun konsep, serta nilai-nilai baru yang diperlukan untuk kehidupannya, dan fokus pembelajarannya diarahkan pada pengembangan keterampilan siswa dalam memproses pengetahuan, menemukan dan mengembangkan sendiri fakta, konsep dan nilai-nilai yang diperlukan (Kemendikbud RI, 2013).

Pembelajaran matematika dengan pendekatan PMRI bertitik tolak pada situasi "real" yang pernah dialami siswa yang merupakan jembatan untuk menghubungkan siswa dari tahap real ke arah formal matematik. Fungsi konteks dalam RME yang juga dikenal dengan Pendidikan Matematika Realistik Indonesia (PMRI) dimana konteks sebagai titik awal bagi siswa dalam mengembangkan pengertian matematika dan sekaligus menggunakan konteks tersebut sebagai sumber aplikasi matematika (Zulkardi dan Putri, 2006). Dalam PISA framework (OECD, 2009) disebutkan bahwa terdapat empat macam situasi yang bisa digunakan untuk konteks, yaitu personal, edukasional, publik, dan ilmiah. Tata surya (Tantriadi, 2013) merupakan salah satu konteks ilmiah yang dapat digunakan dalam proses pembelajaran pengukuran sudut. Penggunaan konteks tersebut dapat dijadikan sebagai starting point yang menjembatani kegiatan siswa dalam memahami konsep pengukuran sudut untuk menghasilkan suatu unit pengukuran dalam menentukan besar sudut.
Materi besar sudut dipelajari secara berkelanjutan di SD dan banyak ditemukan permasalahannya dalam kehidupan sehari-hari, sehingga harus dikuasai siswa dengan baik agar dapat mempelajari materi-materi selanjutnya dengan baik juga sampai jenjang yang lebih tinggi. Dalam proses pembelajaran matematika, pemahaman konsep merupakan landasan yang sangat penting untuk berpikir dalam menyelesaikan suatu permasalahan matematika maupun dalam setiap permasalahan sehari-hari. Senada dengan itu, Mohd Sholeh Abu menyatakan apabila pemahaman konsep dalam pembelajaran matematika tidak tercapai, maka akan mengurangi minat siswa dalam pembelajaran matematika itu sendiri dan siswa akan menganggap bahwa mata pelajaran matematika itu susah (Yahaya, 2010).

Di Indonesia, beberapa hasil penelitian menunjukkan bahwa penerapan pendekatan PMRI memberikan hasil yang lebih baik dibandingkan dengan pembelajaran tradisional. Beberapa penelitian tersebut antara lain adalah; Penelitian yang dilakukan Fauzan (2002), menemukan bahwa hasil pembelajaran geometri siswa kelas IV dan V SD dengan pendekatan matematika realistik pada tes akhir lebih tinggi daripada pembelajaran secara tradisional.

Sementara hasil penelitian dari Ai Nani Nurhayati dan Maulana(2009) menyebutkan bahwa penerapan Pendidikan Matematika Realistik mampu memotivasi dan menarik perhatian siswa. Selain itu dari hasil penelitian dengan Pendidikan Matematika Realistik juga dapat menanamkan konsep operasi perkalian dan pembagian bilangan bulat dngan tingkat penguasaan cukup baik bagi siswa kelas IV SDN Cipanas Tanjungkerta Sumedang, mampu memotivasi dan minat siswa dalam belajar matematika, dan lebih membuat siswa aktif dalam mengikuti pembelajaran matematika. Sejalan dengan penelitian Sari (2017) tentang pengaruh penerapan Pendekatan PMRI terhadap kemampuan pemahaman konsep siswa pada materi besar sudut di kelas VI menyebutkan bahwa terdapat peningkatan pemahaman konsep pada materi besar sudut melalui pendekatan PMRI dengan persentase ratarata dari keseluruhan indikator pemahaman konsep adalah $72 \%$ dengan kategori baik. Penelitian yang dilakukan oleh Sari menggunakan rancangan the one shot-case study.

Berdasarkan pada data rendahnya pemahamam konsep siswa kelas IV SDN Rawa Buaya 03 Pagi 
dan belum pernah diadakan penelitian di sekolah tersebut mengenai materi besar sudut dengan pendekatan PMRI, maka peneliti ingin mengetahui pengaruh penerapan pendekatan PMRI terhadap kemampuan pemahaman konsep matematika pada materi besar sudut di kelas IV SDN Rawa Buaya 03 Pagi.

\section{METODE}

Subjek penelitian adalah mata pelajaran Matematika dengan materi besar sudut dalam waktu 3 kali pertemuan dimana 1 kali pertemuan adalah $2 \mathrm{x}$ 35 menit. Jumlah siswa kelas IV sebanyak 28 siswa yang terdiri dari 13 siswa dan 15 siswi. Penelitian dilaksanakan di SDN Rawa Buaya 03 Pagi yang berlokasi di Jalan Al-Barkah RT.001 RW. 003, Kelurahan Rawa Buaya, Kecamatan Cengkareng, Kota Administrasi Jakarta Barat.

Penelitian ini merupakan penelitian eksperimen dengan menggunakan rancangan one group pretest posttest. Desain ini terdapat pretest sebelum diberi perlakuan. Dengan demikian hasil perlakuan dapat diketahui lebih akurat, karena dapat membandingkan dengan keadaan sebelum diberi perlakuan (Sugiyono, 2010). Hal ini sejalan seperti yang dikemukakan oleh Fraenkel, Wallen dan Hyun yang mengemukakan bahwa In the one group pretest posttest, a single group is measured or observed not only after being exposed to a treatment of some sort, but also before, yang artinya dalam desain one One Group Pretest Posttest, Kelompok tunggal diamati tidak hanya setelah perlakuan tetapi juga diamati sebelum perlakuan. Berikut adalah diagram desain one group pretest posttest (Fraenkel, Wallen \& Hyun, 2012) :

\begin{tabular}{ccc}
\hline $\mathbf{O}$ & $\mathbf{X}$ & $\mathbf{O}$ \\
\hline Pretest & Treatment & Posttest \\
\hline
\end{tabular}

\section{Gambar 2. One Group Pretest Posttest Fraenkel, Wallen \& Hyun}

Cara pengumpulan data dalam penelitian ini adalah dengan menggunakan tes dan observasi. Teknik tes digunakan untuk mengetahui apakah terdapat pengaruh penerapan pendekatan PMRI terhadap kemampuan pemahaman konsep siswa pada materi besar sudut. Observasi dilakukan dengan cara mengamati kegiatan yang sedang dilakukan untuk mengetahui keaktifan siswa. Tes diberikan setelah dilakukan pembelajaran dengan pendekatan PMRI. Dalam pendekatan matematika realistik, setiap siswa dipandang sebagai individu yang memi- liki pengetahuan dan pengalaman sebagai hasil interaksinya dengan lingkungan sekitar. Selanjutnya, dalam pendekatan ini diyakini pula bahwa siswa memiliki potensi untuk mengembangkan sendiri pengetahuannya, danbila siswa diberi kesempatan maka mereka dapat mengembangkan pengetahuan dan pemahaman mereka tentang matematika (Badruddin, 2013).

Sebelum melakukan penelitian, peneliti terlebih dahulu menyusun bahan ajar berupa Rancangan Pelaksanaan Pembelajaran (RPP) dan Lembar Kerja Siswa (LKS). LKS dalam penelitian ini sesuai dengan prinsip dan karakteristik PMRI yang menggunakan konteks "Tata Surya".Konteks tata surya yang dimaksud adalah dengan cara membentuk sudut darisketsa-sketsa gambar tata surya. LKS dalam penelitian ini memuat pertanyaan yang menggiring siswa untuk menemukan sendiri cara menentukan besar sudut, disertai beberapa soal. Penelitian ini menggunakan metode packaging, dengan bantuan alat peraga yang telah disiapkan peneliti. Alat peraga yang digunakan oleh peneliti adalah alat peraga susunan tata surya dan origami berbentuk lingkaran. Pada proses pembelajaran, peneliti menetapkan metode diskusi yang diharapkanakan menampakkan interaktif antara siswa dengan siswa maupun antara guru dengan siswa.

Penskoran dalam penelitian ini akan dihitung dengan menjumlahkan skor yang diperoleh siswa berdasarkan rubrik penskoran yang telah dibuat dengan memunculkan indikator dan deskripsi pada masing-masing indikator pemahaman konsep dengan menggunakan aturan sebagai berikut (Djaali dan Muljono, 2008:103):

$$
T=\frac{J S}{S M} x 100
$$

Keterangan : $\mathrm{T}=$ tes,

$\mathrm{JS}=$ jumlah skor, dan

$\mathrm{SM}=$ skor maksimum.

Indikator yang menunjukkan pemahaman konsep, antaralain(Sari,2011:13-14):(a)menyatakan ulang sebuah konsep, (b) mengklasifikasikan objekobjek menurut sifat-sifat tertentu (sesuai dengan konsepnya), (c) memberikan contoh dan non contoh dari konsep, (d) menyajikan konsep dalam berbagai bentuk representasi matematis, (e) syarat perlu atau syarat cukup suatu konsep, (f) menggunakan, 
memanfaatkan dan memilih prosedur atau operasi tertentu, dan (g) mengaplikasikan konsep atau algoritma pemecahan masalah.

Berikut kaitan indikator-indikator pemahaman konsep matematika siswa terhadap materi besar sudut, yaitu:

Kemampuan menyatakan ulang sebuah konsep merupakan kemampuan siswa untuk mengungkapkan kembali konsep yang telah dikomunikasikan kepadanya. Misalnya, pada saat siswa mempelajari tentang besar sudut siswa dapat menentukan jenis sudut seperti sudut lancip maupun sudut tumpul berdasarkan pengukuran sudut yang mereka peroleh.

Kemampuan mengklasifikasi objek-objek menurut sifat-sifat tertentu (sesuai dengan konsepnya). Misalnya, siswa dapat mengelompokkan objek yang termasuk sudut lancip dan sudut tumpul serta dapat mengurutkan ukuran sudutdari sudut yang paling kecil ke ukuran sudut paling besar berdasarkan besar sudut yang diperoleh.

Kemampuan memberi contoh dan non contoh dari suatu konsep, yaitu kemampuan siswa dalam memberikan contoh dan membedakan antara contoh dengan bukan contoh dari konsep yang mereka telah pelajari. Misalnya, siswa telah mampu menyebutkan jenis sudut yang terbentuk pada jarum jam seperti pukul 10.10 WIB, yaitu sudut tumpul. Sedangkan karet gelang merupakan bentuk lingkaran yang tidak bisa dinyatakan bentuk sudutnya.

Kemampuan menyajikan konsep dalam berbagai bentuk representasi matematis, merupakan kemampuan siswa dalam memaparkan konsep secara berurutan yang bersifat matematis, dapat memaparkan konsep dalam bentuk gambar, tabel, grafik, serta mampu menuliskan kalimat matematika dari suatu konsep. Misalnya, siswa dapat menggunakan ukuran satuan unit yang dihubungkan dengan besar ukuran unit tersebut. Dalam menyajikan data hasil pengukuran besar sudut., siswa dapat menyajikan data hasil pengukuran tersebut kedalam bentuk tabel.

Kemampuan mengembangkan syarat perlu dan cukup suatu konsep. Syarat perlu dapat dimisalkan dengan pernyataan $\mathrm{B}$ merupakan syarat perlu dari pernyataan A, jika B mutlak diperlukan untuk terjadinya $\mathrm{A}$ atau dengan kata lain mustahil ada $\mathrm{A}$ tanpa B. Sedangkan syarat cukup dapat dinyatakan dengan A merupakan syarat cukup dari B, jika A terjadi, maka terjadi B. Misalnya, untuk menentukan besar suatu sudut harus diketahui terlebih dahulu bentuk sudut lancip itu seperti apa. Sehingga satuan unit berupa sudut lancip merupakan syarat perlu yang dapat dijadikan sebagai alat untuk mengukur besar sudut.

Kemampuan menggunakan, memanfaatkan, dan memilih prosedur atau operasi tertentu, maksudnya adalah kemampuan siswa dalam menyelesaikan soal.

Kemampuan mengaplikasikan konsep atau algoritma pemecahan masalah, merupakan kemampuan siswa dalam menggunakan konsep atau prosedur dalam menyelesaikan soal yang berhubungan dengan konsep sehari-hari

Adapun langkah-langkah kegiatan yang dilakukan dalam penelitian ini, sebagai berikut:

Tahap persiapan. Tahap persiapan merupakan tahap awal dalam penelitian.Pada tahap ini dilakukan observasi terhadap sekolah, guru, dan siswa yang akan dijadikan tempat dan objek penelitian serta mempersiapkan segala sesuatu yang berhubungan dengan Kegiatan Belajar Mengajar (KBM).

Tahap pelaksanaan. Penelitian ini dilakukan sebanyak 3 kali pertemuan.Dimana 1 kali pertemuan adalah 2 x 35 menit.Pada pertemuan pertama dan kedua dilakukan tes awal dan pemberian materi. Sedangkan tes akhir dilaksanakan pada pertemuan ketiga untuk melihat hasil akhir dari penelitian.

Tahap pelaporan Setelah melakukan evaluasi langkah selanjutnya menganalisa data.Analisa data yang dilakukan meliputi 7 indikator pemahaman konsep. Hasil belajar yang diperoleh siswa dihubungkan dengan 7 indikator pemahamanan konsep yang kemudian ditarik kesimpulan.Tes dalam penelitian ini adalah tes tertulis. Pemberian tes bertujuan untuk mengetahui kemampuan konsep siswa dalam menyelesaikan soal materi besar sudut. Jumlah soal yang diberikan adalah 5, dimana setiap soal mengandung indikator pembelajaran dan 7 indikator kemampuan pemahaman konsep.

Data kemampuan siswa diperoleh dengan memeriksa lembar jawaban latihan, dan tes tertulis. Kemudian data tersebut dianalisa untuk melihat pencapaian kemampuan konsep siswa dalam menyelesaikan soal.Berikut langkah-langkah dalam menganalisa data hasil tes :Membuat kunci jawaban disertai skor masing-masing jawaban soal, Memeriksa jawaban siswa, Memeriksa skor dan hasil jawaban siswa sesuai dengan skor patokan yang telah ditentukan berdasarkan nilai per indikator, 
Menentukan nilai rata-rata penskoran pemahaman konsep berdasarkan nilai per indikator.

\section{HASIL DAN PEMBAHASAN}

Penelitian ini dilakukan dalam 3 kali pertemuan melalui tiga tahapan, Adapun kegiatan dari ketiga tahapan tersebut adalah sebagai berikut.

Pertemuan pertama, siswa diberikan tes tertulis sebagai tes awal. Tes awal ini bertujuan untuk mengetahui pengetahuan awal siswa tentang materi besar sudut. Tes yang diberikan berupa tes uraian yang berjumlah 3 soal. Setelah selesai mengerjakan soal, siswa diminta untuk duduk berkelompok dengan kelompok yang telah ditentukan oleh guru. Setiap kelompok ada yang berjumlah 4 siswa yang terbentuk menjadi 7 kelompok. Guru memberikan informasi tentang benda-benda apa saja yang mempunyai besar sudut dan apa manfaatnya mempelajari tentang besar sudut. Pada LKS 1, siswa diinstruksikan untuk membentuk sudut dari sketsa-sketsa gambar tata surya yang tersedia di dalam LKS 1 dengan tujuan mengarahkan siswa menentukan jenis sudut.

Selanjutnya, siswa diarahkan kembali untuk menentukan besar sudut melalui perbandingan bentuk sudut-sudut yang telah mereka peroleh. Siswa dapat membandingkan kedua sudut yang terbentuk antara sudut kecil dibandingkan dengan sudut besar. Terdapat beberapa unit yang dihasilkan oleh sudut besar terhadap sudut kecil, sehingga besarnya sudut tersebut adalah 4 kali sudut kecil. Setelah siswa menemukan konsep mengenai besar sudut, siswa diarahkan dan dibimbing untuk membuat kesimpulan atas kegiatan yang telah mereka lakukan. Dari hasil jawaban siswa, mereka menyimpulkan bahwa cara mengukur sudut dengan membandingkan sudut terbesar dan sudut terkecil akan menghasilkan unit pengukuran, unit pengukuran yang digunakan adalah sudut terkecil dalam menentukan besar sudut. Setelah menyelesaikan LKS, perwakilan dari masing-masing kelompok diminta untuk mempresentasikan hasil jawaban kelompok. Diakhir pembelajaran, guru bersama siswa merangkum pembelajaran dan guru juga memberikan tes evaluasi yang berjumlah 2 soal untuk mengetahui sejauhmana pemahaman konsep siwa tentang materi.

Pertemuan kedua, diawal pembelajaran guru mengkondisikan siswa untuk tetap duduk berkelompok. Guru melakukan tanya jawab mengenai materi yang telah dipelajari sebelumnya untuk memantapkan konsep siswa tentang besar sudut, serta mem- berikan informasi tentang materi yang akan dipelajari pada pertemuan kedua ini. Selanjutnya, guru membagikan LKS 2 yang memuat tentang menentukan besar sudut dengan menggunakan origami berbentuk lingkaran. Origami tersebut dilipat dengan ukuran sama besar sehingga menghasilkan delapan unit. Selanjutnya siswa menggunakan bagian unit origami berbentuk lingkaran untuk mengukur besar sudut.Besar sudut satu unit lipatan kertas origami adalah 45 derajat.Setelah melakukan pengukuran tersebut, hasil yang diperoleh siswa disajikan dalam bentuk tabel.

Pertemuan ketiga, siswa diberikan tes terakhir pada pertemuan ini. Tes terakhir bertujuan untuk mengetahui secara keseluruhan tentang materi yang telah dipelajari. Berbeda dengan pertemuan satu dan dua, pada pertemuan ketiga ini siswa dikondisikan duduk secara individu. Soal yang diberikan berjumlah 5 soal uraian yang mencakup indikator pembelajaran dan indikator pemahaman konsep. Dari kegiatan pembelajaran yang dilakukan, muncul semua prinsip dan karakteristik PMRI dan dapat mengukur kemampuan pemahaman konsep siswa. Pembelajaran PMRI memiliki 3 prinsip yaitu menemukan kembali, fenomena terdidik, dan pengembangan model sendiri. Dalam pelaksanaannya, PMRI memiliki 5 karakteristik yaitu menggunakan konteks, menggunakan model, menggunakan kontribusi siswa, interaktivitas dan intertwining (Zulkardi, 2010).

\section{Kemampuan Pemahaman Konsep Berdasarkan Nilai Kriteria Ketuntasan Minimal (KKM)}

Setelah dilakukan penelitian, diperoleh data dari nilai kemampuan pemahaman konsep berupa pretest, latihan dan posttest dari kelas treatment dengan 28 siswa sebagai berikut: mean 75,71, median 80 , modus 80 , nilai tertinggi 90 , dan nilai terendah 50,dan simpangan baku sebesar 25,40.

\begin{tabular}{|c|c|c|c|c|}
\hline No & $\begin{array}{l}\text { Kategori Pema- } \\
\text { haman Konsep }\end{array}$ & $\begin{array}{l}\text { Rent- } \\
\text { ang } \\
\text { Nilai }\end{array}$ & $\begin{array}{l}\text { Fre- } \\
\text { kue- } \\
\text { nsi }\end{array}$ & $\begin{array}{l}\text { Per- } \\
\text { sen- } \\
\text { tase }\end{array}$ \\
\hline 1 & Kurang & $\leq 66$ & 4 & 14 \\
\hline 2 & Cukup & $67-77$ & 7 & 25 \\
\hline 3 & Baik & $78-88$ & 12 & 43 \\
\hline \multirow[t]{2}{*}{4} & Sangat Baik & $89-100$ & 5 & 18 \\
\hline & Jumlah & & 28 & 100 \\
\hline
\end{tabular}


Pada tabel 1, untuk rentang nilai pada kategori pemahaman konsep dibuat berdasarkan standar KKM matematika kelas IV di SDN Rawa Buaya 03 Pagi yaitu 67. Dari tabel tersebut dapat dilihat bahwa setelah menggunakan pendekatan PMRI dalam pembelajaran matematika, siswa yang memiliki kemampuan pemahaman konsep matematika dalam kategori sangat baik sebanyak 5 siswa dari 28 siswa atau sebesar $18 \%$, pemahaman konsep dalam kategori baik memiliki frekuensi terbanyak yaitu 12 siswa atau sebesar 43\%,pada kategori cukup terdapat 7 siswa atau sebesar $25 \%$ dan pada kategori kurang terdapat 4 siswa atau sebesar $14 \%$. Berdasarkan observasi, siswa yang termasuk kategori kurang pada saat pembelajaran kurang mengikuti dan tidak memperhatikan hal yang didiskusikan serta hampir seluruh soal tidak diselesaikan dengan baik.

Sedangkan dalam penelitian sebelumnya yang dilakukan Sari (2017) siswa yang memiliki kemampuan pemahaman konsep matematika dalam kategori sangat baik sebanyak 5 siswa dari 32 siswa (15.63\%), pemahaman konsep dalam kategori baik yaitu 17 siswa $(53.12 \%)$, pada kategori cukup terdapat 6 siswa (18.75\%) dan pada kategori kurang kategori kurang terdapat 4 siswa (12.5\%). Penelitian sebelumnya menggunakan metode one shotcase study dimana tidak dilakukan pre test terlebih dahulu. Apabila dibandingkan dengan penelitian sebelumnya, penelitian ini untuk kategori sangat baik lebih unggul yaitu $18 \%$.

Dari hasil belajar siswa kelas IV sebelum menggunakan metode pendekatan matematika realistik Indonesia diperoleh hasil bahwa hanya ada 8 siswa (29\%) dari 28 siswa yang memenuhi KKM. Apabila hasil belajar siswa ini dibandingkan dengan hasil belajar siswa setelah menerapkan metode PMRI akan diperoleh hasil bahwa terjadi peningkatan hasil belajar siswa yang semula hanya 8 siswa (29\%) yang memenuhi KKM meningkat menjadi 24 siswa (86\%). Dengan demikian dapat dikatakan terjadi peningkatan $57 \%$ hasil belajar matematika siswa dengan menerapkan metode PMRI. Hal ini sejalan dengan penelitian yang dilakukan Fauzan (2002), menemukan bahwa hasil pembelajaran geometri siswa kelas IV dan V SD dengan pendekatan matematika realistik pada tes akhir lebih tinggi daripada pembelajaran secara tradisional.

\section{Indikator Pemahaman Konsep}

Pada saat proses pembelajaran, siswa sangat antusias dalam mengerjakan tiap soal pada lembar aktivitas berdasarkan soal yang ada dan dengan pengamatan penggunaan konteks tata surya. Pendesainan aktivitas ini mengacu pada lima karakteristik PMRI yakni pembelajaran harus diawali dengan penggunaan konteks yang bertujuan untuk meningkatkan motivasi dan ketertarikan siswa dalam belajar (de Lange dalam wijaya, 2012). Siswa diberikan tes awal (pretest) dan tes akhir (postest). Dari kedua tes ini, peneliti memperoleh informasi bahwa hasil pekerjaan siswa menunjukkan ada perbedaan antara tes awal (pretest) dan tes akhir (postest) dalam memahami konsep besar sudut. Ketika tes awal (pretest) masih banyak siswa yang belum mampu menjawab sebagian besar dari soalsoal yang diberikan. Tetapi pada tes akhir (postest) siswa telah mampu menyelesaikan berbagai permasalahan tentang besar sudut. Tidak hanya itu, di akhir aktivitas beberapa siswa juga telah mampu mengungkapkan penalarannya dengan baik.

Adapun persentase kemunculan masing-masing deskripsipemahaman konsep siswa dapat dilihat pada tabel 2.

Berdasarkan tabel tersebut dapat diketahui persentase rata-rata keseluruhan indikator pretest, latihan dan posttest dari ketujuh indikator pemahaman konsep. Persentase rata-rata keseluruhan indikator saat pretest sebesar 72,71, latihan 79,28, dan postest 83,42 .Adapun uraian rata-rata dari masingmasing ketujuh indikator pada pemahaman konsep sebagai berikut: (a) Kemampuan menyatakan ulang sebuah konsep memiliki rata-rata $67 \%$ dengan kategori cukup, (b) kemampuan mengklarifikasikan objek menurut sifat-sifat tertentu sesuai dengan konsep sebesar 78\% dengan kategori baik, (c) kemampuan memberikan contoh dan bukan contoh sebesar $89 \%$ dengan kategori sangat baik, (c) kemampuan menyajikan konsep dalam berbagai bentuk representasi matematika sebesar $60 \%$ dengan kategori kurang, (d) kemampuan mengembangkan syarat perlu dan syarat cukup dari suatu konsep sebesar 78\% dengan kategori baik, (e) kemampuan menggunakan, memanfaatkan dan memilih prosedur tertentu sebesar $89 \%$ dengan kategori sangat baik, (f) kemampuan mengklasifikasikan konsep/ algoritma ke pemecahan masalah sebesar $89 \%$ dengan kategori sangat baik. 
Tabel 2. Persentase Kemunculan Masing-Masing IndikatorPemahaman Konsep

\begin{tabular}{|c|c|c|c|c|c|c|}
\hline \multirow[b]{2}{*}{ No } & \multirow[b]{2}{*}{ Indikator Pemahaman Konsep } & \multicolumn{3}{|c|}{ \% Kemunculan } & \multirow{2}{*}{$\begin{array}{l}\text { Rata-rata } \\
\text { Persentase } \\
(\%)\end{array}$} & \multirow[b]{2}{*}{ Kategori } \\
\hline & & Pretest & Latihan & Posttest & & \\
\hline 1. & $\begin{array}{l}\text { Kemampuan menyatakan ulang } \\
\text { sebuah konsep } \\
\text { Kemampuan mengklarifikasikan }\end{array}$ & 58 & 67 & 76 & 67 & Cukup \\
\hline 2. & objek menurut sifat-sifat tertentu & 69 & 79 & 85 & 78 & Baik \\
\hline 3. & $\begin{array}{l}\text { sesuai dengan konsep } \\
\text { Kemampuan memberikan contoh } \\
\text { dan bukan contoh } \\
\text { Kemampuan menyajikan }\end{array}$ & 87 & 91 & 89 & 89 & $\begin{array}{l}\text { Sangat } \\
\text { Baik }\end{array}$ \\
\hline 4. & $\begin{array}{l}\text { konsep dalam berbagai bentuk } \\
\text { representasi matematika } \\
\text { Kemampuan mengembangkan }\end{array}$ & 54 & 58 & 69 & 60 & Kurang \\
\hline 5. & $\begin{array}{l}\text { syarat perlu dan syarat cukup dari } \\
\text { suatu konsep }\end{array}$ & 69 & 78 & 87 & 78 & Baik \\
\hline 6. & $\begin{array}{l}\text { Kemampuan menggunakan, } \\
\text { memanfaatkan dan memilih } \\
\text { prosedur tertentu } \\
\text { Kemampuan mengklasifikasikan }\end{array}$ & 86 & 91 & 89 & 89 & $\begin{array}{l}\text { Sangat } \\
\text { Baik }\end{array}$ \\
\hline 7. & $\begin{array}{l}\text { konsep/algoritma ke pemecahan } \\
\text { masal }\end{array}$ & 86 & 91 & 89 & 89 & $\begin{array}{l}\text { Sangat } \\
\text { Baik }\end{array}$ \\
\hline $\begin{array}{l}\text { Per: } \\
\text { indi }\end{array}$ & $\begin{array}{l}\text { atase rata-rata keseluruhan } \\
\text { tor }\end{array}$ & 72,71 & 79,28 & 83,42 & 78,57 & Baik \\
\hline
\end{tabular}

Dengan demikian secara keseluruhan, persentase rata-rata kemunculan seluruh indikator pemahaman konsep adalah $78,57 \%$ dengan kategori baik.Hal ini sesuai dengan yang dikemukakan Sari (2013) bahwa dengan menggunakan PMRI dalam pembelajaran matematika kemampuan representasi matematis siswa menjadi lebih baik. Dari data diatas juga dapat dilihat peningkatan pemahaman konsep dari pretest, latihan hingga posttest.

Pembelajaran ini didesain untuk melihat peran konteks yang mendukung pemahaman konsep siswa. Peran konteks yang didesain telah membantu siswa untuk paham terhadap konsep dalam memahami pengukuran sudut. Hal ini bertujuan untuk memahami konsep pengukuran sudut melalui aktivitas-aktivitas yang dilakukan untuk menjadikan siswa tidak mengalami kesulitan dalam memahami materi. Menurut Soedjadi (2007: 2) penyebab kesulitan siswa belajar matematika bisa bersumber dari dalam diri siswa maupun dari luar siswa, misalnya cara penyajian materi pembelajaran atau suasana pembelajaran dilaksanakan.

Berdasarkan desain lintasan belajar yang telah dirancang dan dilakukan oleh peneliti, lintasan belajar untuk memahami konsep pada pembelajaran besar sudut meliputi mengenal dan mengetahui unit pengukuran yang digunakan dalam pengukuran sudut (melalui sistem tata surya untuk membandingkan sudut-sudut yang terbentuk antara hubungan 2 planet dengan matahari sebagai titik pusat). Pendekatan PMRI, serangkaian urutan kegiatan dan beberapa konsep besar sudut menjadi acuan utama dalam setiap aktivitas pembelajaran.

Pembelajaran yang dilaksanakan menggunakan konteks sistem tata surya sebagai starting point untuk mengawali materi tentang besar sudut. Susunan atau peredaran planet-planet dalam sistem tata surya memiliki konsep dalam memahami besar sudut yaitu sebagai unit pengukuran/unit ukur. Seperti yang diungkapkan Clements dan Sarama (2009) bahwa metode pengukuran sudut didasarkan pada pembagian lingkaran. Seperti panjang dan luas yang dasar pengukurannya terletak pada pemahaman konsep-konsep seperti partisi yang sama dan satuan iterasi untuk memahami sudut dan ukurannya (Clements dan Stephan, 2004; Clements dan Sarama, 2009 ).

\section{SIMPULAN DAN SARAN}

\section{Simpulan}

Berdasarkan hasil penelitian, dapat disimpulkan bahwa terdapat peningkatan hasil belajar siswa dan pemahaman konsep pada materi besar sudut melalui pendekatan PMRI. Adapun peningkatannya hasil belajar matematika siswa dengan menerapkan metode pendekatan matematika realistik Indonesia sebesar 57\%. Dengan demikian pendekatan PMRI dapat membantu siswa memahami konsep materi besar sudur sehingga hasil belajar matematika 
siswa materi besar sudut meningkat. Persentase rata-rata yang diperoleh dari keseluruhan indikator pemahaman konsep sebesar $76 \%$ dengan kategori baik.

\section{Saran}

Berdasarkan hasil penelitian ini, peneliti dapat memberikan saran diantaranya:(a) Siswa diharapkan meningkatkan ketelitian dalam pengukuran sudut dengan mengikuti petunjuk soal, (b) dalam memilih metode pembelajaran, sebaiknya guru memilih menggunakan metode pembelajaran yang inovatif, seperti pendekatan PMRI, dan (c) sebaiknya guru menggunakan media pembelajaran sebagai alat bantubagi siswa untuk memudahkan siswa memahami konsep matematika yang disesuaikan dengan materi dan metode pembelajaran.

\section{DAFTAR RUJUKAN}

Badruddin, E. 2013. Implementasi Pendekatan Realistik Pada Pembelajaran Operasi Bilangan Real Untuk Meningkatkan Hasil Belajar Siswa SMK Negeri 5 Telkom Banda Aceh. Jurnal Peluang Volume 2. Nomor 1.

Brummelen, H.V. 2008. Batu Loncatan Kurikulum: Berdasarkan Alkitab. Jakarta: Universitas Pelita Harapan.

Clements, D.H. \& Sarama, J. 2009.Learning and teaching early math: The learning trajectories approach. New York: Routledge.

Clements, D.H. \& Stephan, M. 2004.Measurement in Pre-K to Grade 2 Mathematics.In D. H. Clements, J. Sarama, \& A.-M. Dibiase (Eds.), Engaging Young Children in Mathematics: Standard for Early Childhood Mathematics Education (pp. 299-320). New Jersey: Lawrence Erlbaum Associates.

Damaruta.2015. Belajar Kurikulum 2013 Membantu Siswa Belajar Mandiri. (Online), diunduh 9 Mei 2018,(http://www.damaruta. com/2015/02/halaman-121-manfaat-sudutdalam.html?m=1).

Darsono.2010. Jurnal Pembelajaran Matematika Realistik Indonesia Suatu Inovasi Dalam Pendidikan Matematika Di Indonesia.(Online), diunduh 2 Agustus 2015, (https://nazwandi. wordpress.com/2010/06/22/jurnalpmripembelajaran-matematika-realistik-indonesiasuatu-inovasi-dalam-pendidikan-matematikadi-indonesia).
Djaali, dan Muljono, P. 2008.Pengukuran Dalam Bidang Pendidikan. Jakarta: PT Grasindo.

Fauzan, A. 2002.Applying realistics mathematics education (rme) in theaching geometry in indonesian primary schools. Den Haag: CIPGegevens Koninklijke Bibliotheek.

Fraenkel, J.R., Wallen, N.E. \& Hyun, H.H. 2012. How To Design and Evaluate Research in Education. New York : McGrow-Hill.

Husna, R.\& dkk. 2013. Peningkatan kemampuan pemecahan masalah dan komunikasi matematika melalui pendekatan matematika realistik pada siswa SMP Kelas VII Langsa. Jurnal Pendidikan Matematika, PARADIKMA $6(2)$.

Kemendikbud. 2013. Kurikulum 2013 Kompetensi Dasar Sekolah Dasar (SD)/Madrasah Ibtidaiyah (MI). Jakarta: Kemendikbud.

Kemendikbud.2013. Pedoman Pemberian Bantuan Implementasi Kurikulum Tahun 2013. Jakarta: Kemendikbud.

Lehrer, R. 2003. Developing Understanding of Measurement. In J. Kilpatrick, W. G. Martin, \& D. E. Schifter (Eds.), A research companion to principles and standards for school mathematics. Reston, VA: National Council of Teachers of Mathematics.

Nurhayati, A.N. \& Maulana.(2009, Oktober). Penerapan pendekatan matematika realistik dalam penananaman konsep perkalian dan pembagian bilangan bulat.Makalah disajikan dalam Konferensi Pendidikan Dasar I Tingkat Internasional, di Universitas Pendidikan Indonesia Kampus Sumedang.

OECD. 2009. PISA 2009 Assessment Framework - Key Competencies in Reading, Mathematics and Science. Paris: OECD.

Oftiana, S. dan Saefudin, A.A. 2017. Pengaruh Pendekatan Pembelajaran Matematika Realistik Indonesia (PMRI)Terhadap Kemampuan Pemecahan Masalah Matematika Siswa Kelas VII SMP Negeri 2 Srandakan. Jurnal Matematika dan Pembelajaran, Volume 5, No. 2.

Sari, P. 2011. Pengaruh Contextual Teaching and Learning (CTL) Terhadap Kemampuan Pemahaman Konsep Matematika Siswa SMA Taruna Indonesia Palembang.Skripsi Tidak dipublikasikan. Pelembang: Universitas PGRI Palembang. 
Sari, R.N.2013.Pembelajaran MateriPerbandingan Menggunakan Pendekatan PMRI untuk Mengetahui Kemampuan Representasi Matematis Siswa Kelas VII SMP. Skripsi. Palembang: FKIP Universitas Sriwijaya.

Sari, P. 2017. Pemahaman Konsep Matematika Siswa Pada Materi Besar Sudut Melalui Pendekatan PMRI. Jurnal Gantang, Vol. II, No. 1, Maret 2017.

Saefudin, A.A. 2012. Pengembangan Kemampuan Berpikir Kreatif Siswa Dalam Pembelajaran Matematika Dengan Pendekatan Pendidikan Matematika Realistik Indonesia (PMRI). Yogyakarta: Journal UNY.

Sembiring, R.K. 2007. PMRI: History, Progress and Challenges. Paper presented atthe Earcome4. Penang, Malaysia.

Sugiyono. 2010. Metode Penelitian Pendidikan (Pendekatan kuantitatif, kualitatif dan $R \& D$ ). Bandung: Alfabeta.

Tantriadi, Y. 2013. Pembuatan Ensiklopedia Interaktif Tata Surya Untuk Anak SMP. Dalam Jurnal Ilmiah Mahasiswa,Universitas Surabaya, Volume 2, Nomor 1.
Yahaya, A. 2010.Kepentingan Kepahaman Konsep dalam Matematik. Malaysia: Universiti Teknologi Malaysia.

Zandieh, M. \& Rasmussen, C. (2010).Defining as a mathematical activity: a framework for characterizing progress from informal to more formal ways of reasonng.Journal of Mathematics Behavior, 229, 57-75.

Zulkardi. 2002. Developing a learning environment on realistic mathematics education for Indonesian student teacher. Den Haag: CIPGegevens.

Zulkardi dan Putri, R.I. 2006.Mendesain Sendiri Soal Kontekstual Matematika.Prosiding in Konferensi Nasional Matematika ke 13. Semarang: Indonesia.

Zulkardi dan Ratu, I. 2010.Pengembangan Blog Support untuk Membantu Siswa dan Guru Matematika Indonesia Belajar Pendidikan Matematika Realistik Indonesia (PMRI).JIPPBalitbang. 